\title{
Impact of Baron Tourism Areas on Local Economic Development and Changes in Land Use in Gunungkidul Regency
}

\author{
Ratika Tulus Wahyuhana $^{1 *}$, Annisa Mu'awanah Sukmawati ${ }^{1}$, Lilla Fitri Annisa ${ }^{1}$, \\ Ihza Iskandar Yusuf ${ }^{1}$
}

${ }^{1}$ Faculty of Sains and Technology, University of Technology Yogyakarta

"Corresponding author. Email: ratika.wahyuhana@staff.uty.ac.id

\begin{abstract}
Baron area is a tourism superior area in Gunungkidul. Based on the Tourism Development Master Plan (RIPPDA) of Gunungkidul Regency, the Baron Region is an integrated area with functions in the education and tourism sector. The supported by the existence of the Baron Coast area as marine tourism and Baron Techno Park as an educational tourism. The study question here is: How the impact of the existence Baron tourism area on social-economic aspects of the community and land-use change? The problems that arise the development of Baron tourism area are the unintegrated development between tourism objects and the uneven economic impact, so the researchers want to examine the impact that the tourism area has on the economic aspects of the local community and land-use change. The research approach uses a quantitative approach with quantitative descriptive analysis and time series mapping analysis methods. The technique used is purposive sampling technique based on data sources obtained from primary data through field observations and interviews. The results of the research study show that the influence of tourism on economic aspects predominantly only occurs in Baron Beach. The influence is change in employment opportunities and shifts in types of work from fishers to tourist attraction businesses. The change in land use is indicated by development of attractions and businesses supporting the tourism sector, namely trade and services from recent years. While the influence of economic aspects for the business community in Baron Technopark is still minimal. It can be concluded that there has not been integration between attractions in the Baron Region on the improvement of the people's economy. It is necessary to develop an integrated tourism area both in terms of spatial pattern and structure with integration marketing, distribution locations and connectivity between tourist objects.
\end{abstract}

Keywords: local economic development, Gunungkidul Regency, tourism

\section{INTRODUCTION}

Tourism can be used as a catalyst for tourism development activities and form a long chain that can move to a variety of activities in society [1]. As one of the development sectors that can spur economic growth in a region, tourism is considered a strategic asset to encourage development in certain areas that have the potential for attractions. In addition to its role, tourism is also a sector that is not much different from other economic sectors, namely, in the development process, it also has an interest or development in land use and social economy.

Tourism development has caused changes in land use, social, and economic aspects [2]. The influence of tourism on the physical aspects is the change in land use while the influence of social and economic aspects includes changes in employment and income, the pattern of division of labor, employment, and business opportunities.

The economic opportunities contained in the tourist area spur the growth of tourism support facilities [3]. It is developing economic activities in the tourism sector, such as hotels, lodging, restaurants, handicraft industries, and other supporting facilities [4]. The development of tourism activities accompanied by economic opportunities, changes to the physical condition of the region. Land that has used for agriculture and settlements is converted into hotel buildings so on.

The Baron area is one of the leading tourism destinations in Gunungkidul Regency. Administratively, the Baron Area development plan covers two sub-districts, namely Saptosari and Tanjungsari Districts, Gunungkidul Regency. In the 2011 Baron Area Development Master Plan, it was explained that the efforts to develop the Baron Area include the Baron Beach as a nature tourism and the Baron Technopark (BTP) as an educational tourism.

Attractions that develop are the Baron Beach and Baron Technopark. This tourism area has the potential to contribute to the development and development of the region. based on the Tourism Development Master Plan (RIPPDA) of Gunungkidul Regency, the Baron area is one of the leading tourist areas in Gunungkidul Regency [5]. In this regard, research is needed to be able to determine the effect of the Baron tourism area on economic aspects and 
land-use changes. Based on the purpose of the research, the substance limits studied in this study include the characteristics of attractions, visitors, business people, and analyzing the influence of the Baron tourism area on the economic aspects of society and land-use changes.

The scope of the area in this study is the Baron tourist area located in Saptosari District and Tanjungsari District, Gunungkidul Regency.

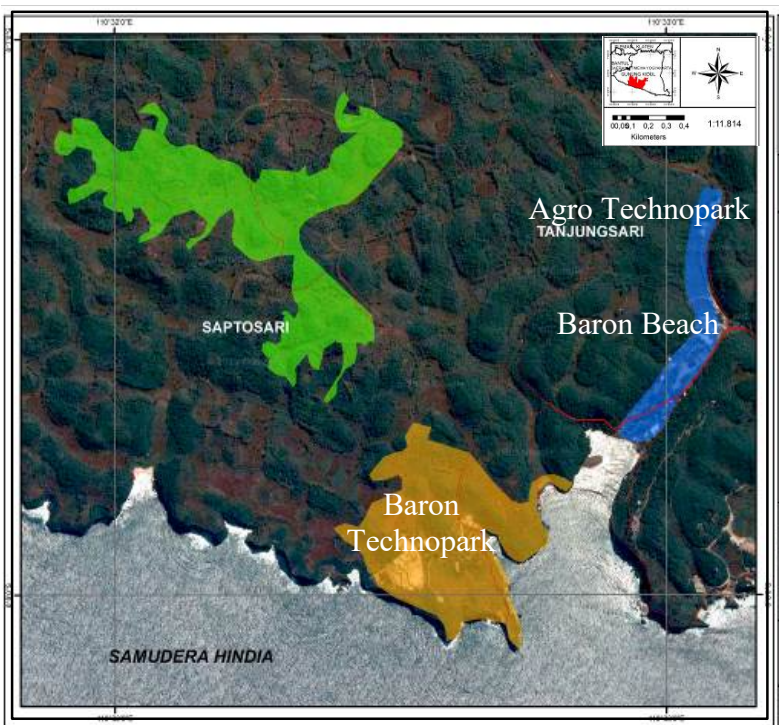

Figure 1 Administration of Baron Area

\section{METHOD}

\subsection{Criteria}

The approach method used in this research is a quantitative approach method using deductive thinking patterns, in which the implementation of research is based on existing theories as a provision of research in the field. The sampling technique used in this study was purposive sampling aimed at business operators in tourist attractions. Data sources in the form of primary and secondary data. Data collection techniques consisted of interviews, questionnaires, and documentation.

\subsection{Samples}

In this study, the sample used in this study was 102 people. Based on the Functional Tourism system, the tourism experiments conducted are a sample of the community, service, and involvement components. For the process of data analysis using simple regression analysis, t-test, and the determinant coefficient (R2) with tourism development as the $\mathrm{X}$ variable (independent) and increasing people's income as the $\mathrm{Y}$ variable (dependent). The community income variable consists of 4 indicators: age of business, length of work, education level, and total income. Meanwhile, the variable of tourism development is related to the addition of locations, tourism promotion, accessibility, access and infrastructure, and accommodation.

\section{RESULT AND DISCUSSION}

In this section, the authors describe the characteristics of Baron Region Tourism and influence of the Baron tourist area on changes in economic aspects of communities and land use changes. The results divide into three parts: characteristics of Baron region tourism, economic impact, and land use change.

\subsection{Characteristics of attractions of the demand component (demand) and supply}

\subsubsection{Characteristics of attractions of the demand component (demand) can in the variable number of visitors}

Characteristics of attractions of the demand component (demand) in Baron Beach and Baron Technopark can in the variable number of visitors in the following figure:

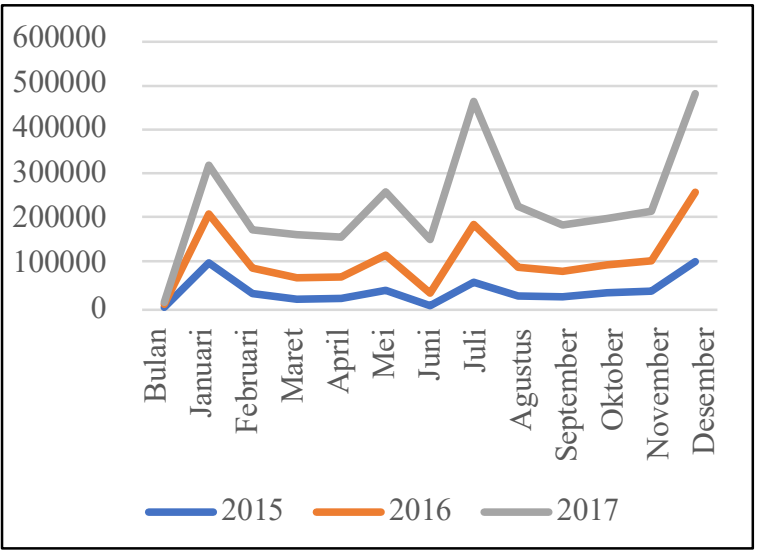

Figure 2 Tourist Visit Trends in Baron Beach

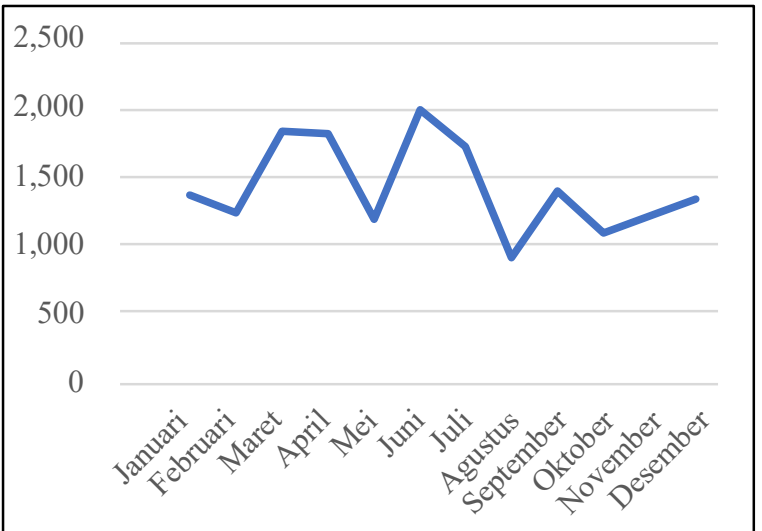

Figure 3 Tourist Visit Trends in Baron Technopark 
In Baron Beach, the most significant percentage increase in visitors occurred in 2016 to 2017 amounted to $83.70 \%$. This condition influence by new attractions namely jeep tourism and also the development of boat tourism. The number of visitors to Baron Technopark is quite volatile and tends to decrease. Baron Technopark is one of the new tours in the Gunungkidul Regency.

\subsubsection{Characteristics of attractions from the supply component (offer) from the attraction of attractions and tourist services provided at the tourist attraction.}

a. Baron Beach

Attractions and tourist services at Baron Beach include boat tours and jeep tours and supporting facilities such as fish auctions (TPI), culinary and souvenir sales, and lighthouse areas that can be used to see the beauty of the beach from above.
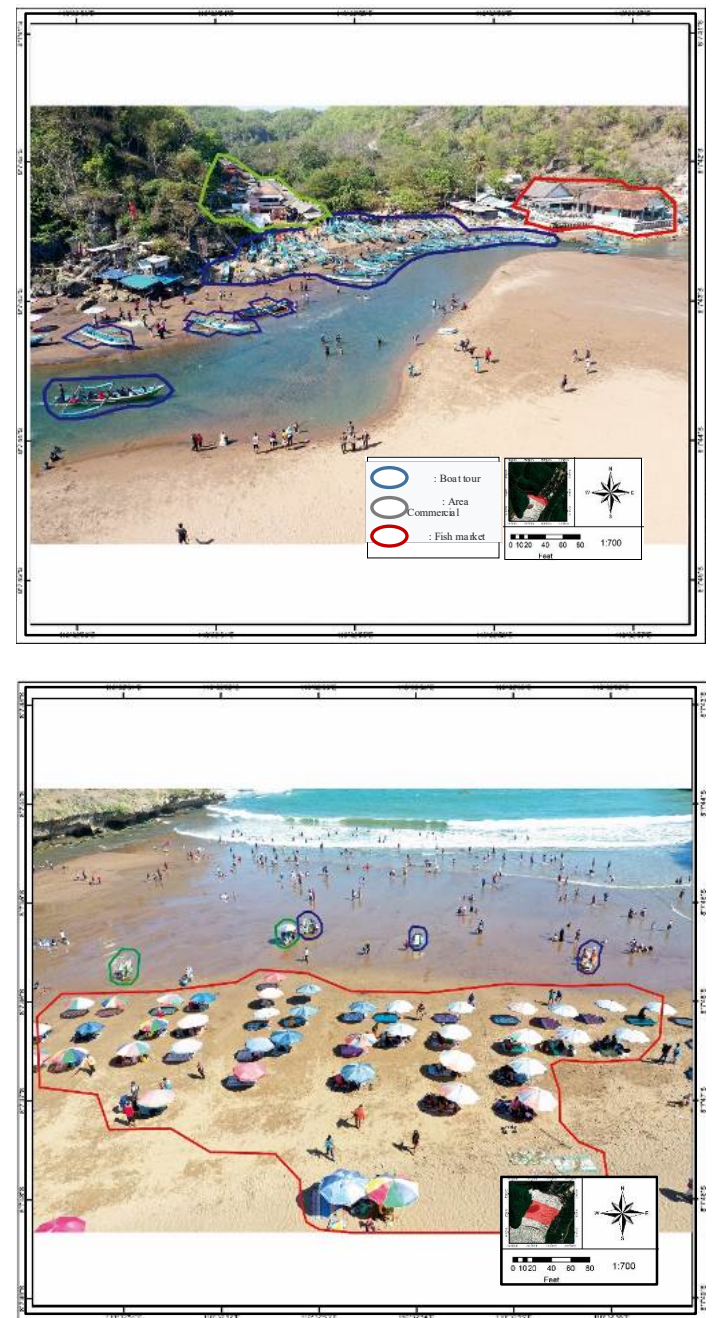

Figure 4 Orthophoto of Distribution of Economic Activities in Baron Beach Tourism Area

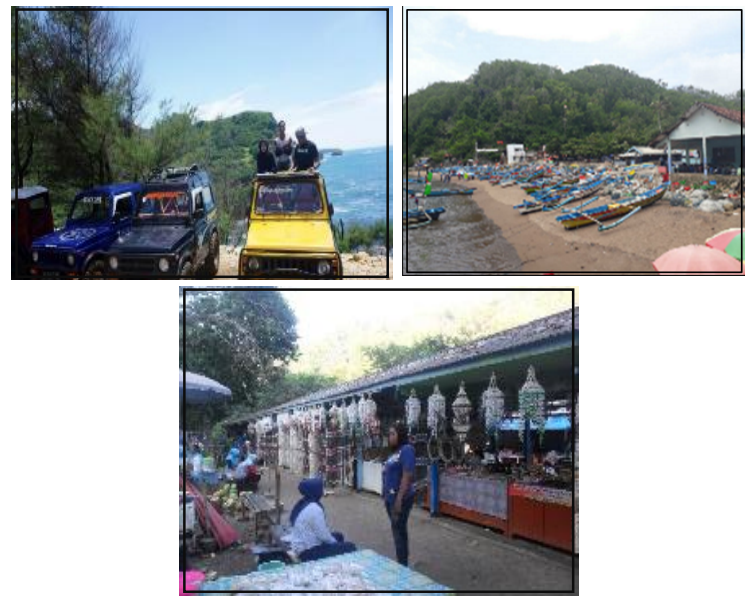

Figure 5 Baron Beach Tourist Attraction and Commercial Area

b. Tourist attraction in Baron Beach

Tourism and tourism services in Baron Technopark as educational tours are sundial, amphitheater, wind power, wave power, and solar power. One of the educational tours that can be enjoyed by visitors to Baron Techno Park is the sundial. The sundial, which located at a height, shows a beautiful view of the sea. The sundial can be learned by visitors to see the shadow on the clock and will show the time with the shadow of the clock Baron Techno Parkis also designed as a training center and display of the use of New Renewable Energy Technology (EBT).

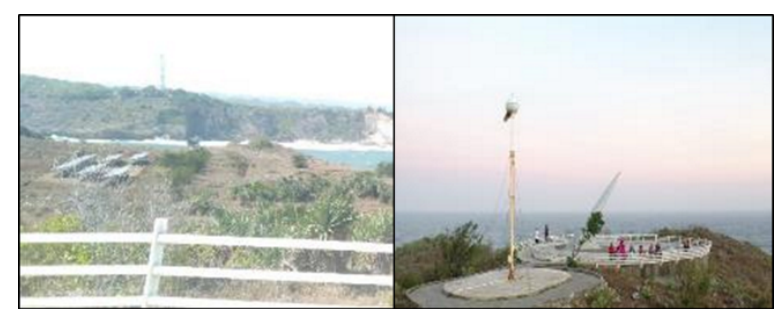

Figure 6 Solar Panel Baron Technopark (left) and Baron Technopark Sun Clock (right)

\subsection{Economic Impact Baron Tourist Area}

a. Baron Beach

With the attractions in the Baron area, including Baron Beach and Baron Technopark, people can make a living from various types of work, such as for people who were unemployed because of limited job opportunities and then take advantage of existing job opportunities. To find out the effect of income level on the community around the Baron Region tourism objects, the following analysis of the effect of the level of income on the community is grouped by type of work.

Based on relevant literature studies, there are similarities regarding the impact of tourism on increasing income and poverty alleviation efforts. Tourism aims one of them to increase income. Tourism can also increase local economic development. The employment opportunities 
available in attractions are expected to increase income and prosper the surrounding community [4].

From the change in the level of income of the overall respondents of business operators in the tourist area, it obtained the average results of the overall income of business respondents in the Baron Coast amounting to Rp 938,443.00. Thus, Baron Beach tourism objects can provide employment opportunities for people in the tourist area to increase income. The average increase in income from respondents of business operators can see in the following figure:

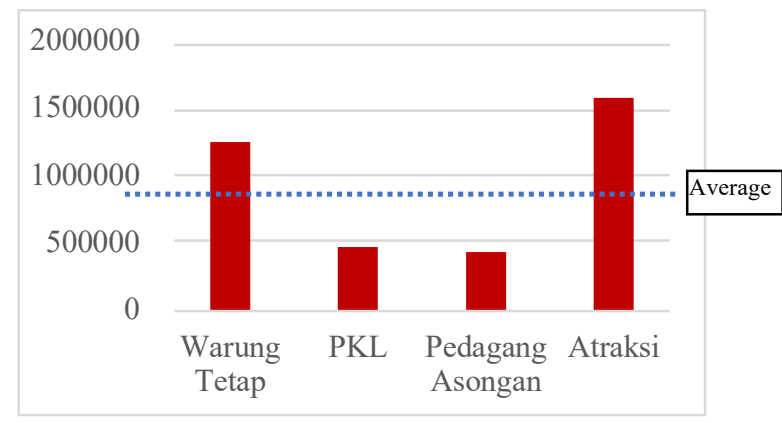

Figure 7 Income from Respondents in Baron Beach

With the existence of Baron Beach tourism objects, in addition to being able to increase people's income, it also shows a shift in people's livelihoods from the main occupation of fishers to attraction business operators, namely boats and jeep tourism.

To determine whether the regression model on tourism development has a significant effect on people's income, perform a T-test. Before concluding the hypothesis that will be accepted, first determine t table 5\%: $2=2.5 \%$ (2sided test) and degrees of freedom (df) $n-k-1$ or $90-1-$ $1=88$. By testing two sides, the results obtained for $\mathrm{t}$ table amounted to 1.991. While $t$ arithmetic on the variable of tourism development of 4,764 and based on significance $<0.05(0,000<0.05)$, it can be concluded that $\mathrm{Ha}$ is accepted Ho rejected. So it can be concluded that the development of tourism affects increasing people's income.

Table 1 Test Results $\mathrm{t}$

\begin{tabular}{|l|l|l|l|l|l|}
\hline Model & \multicolumn{2}{|l|}{$\begin{array}{l}\text { Unstandardize } \\
\text { d Coefficients }\end{array}$} & $\begin{array}{l}\text { Standardized } \\
\text { Coefficients }\end{array}$ & T & Sig. \\
\cline { 2 - 6 } & B & $\begin{array}{l}\text { Std. } \\
\text { Error }\end{array}$ & Beta & & \\
\hline $\begin{array}{l}1 \text { (Constant) } \\
\begin{array}{l}\text { Tourism } \\
\text { Development }\end{array}\end{array}$ & 3,864 & 5,108 & &, 756 &, 451 \\
\hline
\end{tabular}

a. Dependent Variable : Community Income

b. Baron Technopark

In Baron Technopark, there is only one permanent stall and some street vendors whose numbers are not necessarily around 3-6 traders. They sell food and soft drinks and usually only sell on holidays and when there is a visit from the school or agency. The level of income of fixed stalls and hawkers in the Baron Technopark increases only between IDR $100,000.00$ and IDR $400,000.00$ every month.

\subsection{Land Use Change Baron Beach and Baron Technopark}

Land use in Baron Beach for 2009 includes areas for culinary, souvenir sales, fish auction places, boat tours, and lighthouse area. From 2009 to 2018, changes in land use in the Baron Technopark area of 0, $23 \mathrm{Ha}$ include the addition of the road network and the addition of tourist support areas, including culinary and tourist attractions. Changes in land use in Baron Technopark during 2013-2018 amounted to 2.79 ha. Changes in land use are marked by physical development in the form of supporting facilities.

Based on a review of relevant literature, the effect of tourism on physical aspects is the change in land use such as the emergence of various locations for economic activity.[1] Changes in land use of the Baron Beach and Baron Technopark can see in the figure 8 .
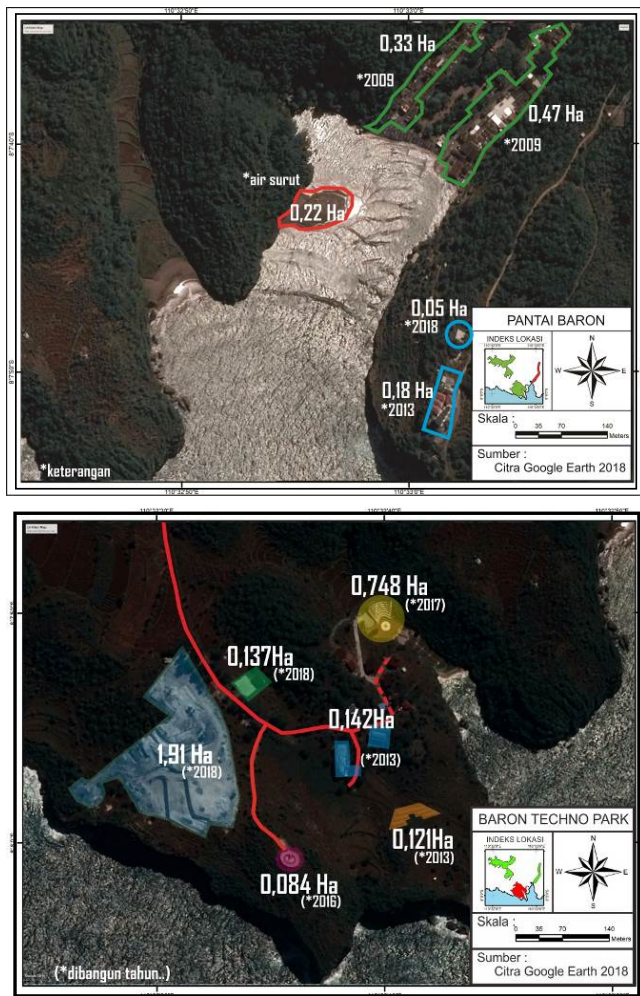

Figure 8 Changes in land use of the Baron Technopark 2009-2018 (left) and Baron Technopark 2013-2018

\section{CONCLUSION}

The results show that the development of the Baron tourist area influences the economic aspects of the surrounding community and changes in land use. On the economic aspect, economic activities in the developing areas of Baron Beach are quite diverse. While in Baron Technopark, it is still very minimal. From the change in income, the employment opportunities in the tourist area can absorb people who initially did not have jobs, especially the local community. 


\section{REFERENCES}

The influence of changes in land use on the coast of Baron is characteristic by the development of boat tourism attractions, tourist jeep attractions, and also the addition of tourist service facilities from 2009-2018 covering an area of 0.23 Ha. Furthermore, in Baron Technopark, the influence of land use was marked by the addition of educational tourism support facilities from 2013 to 2018 with land-use changes of $2.79 \mathrm{Ha}$. There is a need for better planning of the tourist area so that it can increase the number of visitors, especially in Baron Technopark as an educational tour. Baron Technopark and Baron Beach should be able to be developed into a unified structured, and mutually integrated region. The planning of the tourist area in integrated spatial planning can be accommodated.

\section{ACKNOWLEDGMENT}

The authors would like to thank for DRPM Kemenristekdikti and University of Technology Yogyakarta for its research grant and opportunity that enabled the authors to conduct this research. Thank you also conveyed to the Badan Penerapan dan Pengkajian Teknologi Yogyakarta (BPPT), Gunungkidul Regency tourism office and the Baron Beach Tourism Manager.
[1] O. A. Yoeti, Perencanaan dan Pengembangan Pariwisata. Jakarta: Pradnya Paramitatle. Jakarta: Pradnya Paramita, 2018.

[2] I. G. dan I. K. S. D. Pitana, Pengantar Ilmu Pariwisata. Yogyakarta: ANDI, 2009.

[3] S. [7] Mtapuri, O., Giampiccoli, A. \& Jugmohan, "Community-based tourism affinity index: A visitor's approach',' African J. Hosp., vol. 4, no. 2, pp. 1-13, 2015.

[4] A. Saayman, M. \& Giampiccoli, "Community-based and pro-poor tourism: Initial assessment of their relation to community development', 'Eur. J. Tour. Res., vol. 2, no. 1, p. 144, 2016.

[5] Pemerintah Provinsi Daerah Istimewa Yogyakarta, Penyusunan Rencana Induk Pengembangan Kawasan Baron. Kabupaten Gunungkidul, DIY. Kabupaten Gunungkidul, DIY, 2011.

[6] M. Giampiccoli, A., and Saayman, "Community based tourism: From a local to a global push," Indep. Res. J. Manag. Sci., vol. 1, no. 1, pp. 1-10, 2016.

[7] M. Pedrana, "Local economic development policies and tourism: An approach to sustainability and culture," Reg. Sci. Inq. J., vol. 5, no. 1, pp. 91-99, 2013. 